\title{
A obsessão das ideias ou a literatura que fracassa: uma abordagem a partir de Marilene Felinto
}

\author{
The obsession of ideas or literature that fails: \\ an approach based on the works of Marilene Felinto \\ La obsesión de las ideas o la literatura que fracasa: \\ un enfoque desde Marilene Felinto
}

Thiago H. Fernandes ${ }^{* *}$

\section{Resumo}

Este artigo se utiliza da obra de Marilene Felinto para refletir sobre uma obsessão das ideias no campo literário, traçando, para tanto, uma linha entre o seu romance de estreia As mulheres de Tijucopapo (1982) e sua última publicação até o momento, a novela Obsceno abandono: amor e perda (2002). Esclarecida a obsessão em reincidências que problematizam a presença das narradoras, a começar por um estar no fracasso da linguagem, acreditamos que o traço possa esclarecer uma ideia de escrita aproximada da tentativa; escrever como uma volta constante ao próprio gesto de escrever, o que inevitavelmente colocaria em questionamento a literatura, seu poder e valor, igualmente a ideia idealizada de obra, principalmente quando o princípio de desrazão surge em nosso horizonte. Tais questões são circundadas ainda pela análise da corrente sugestão de que, na autora, narrativa de vida e de ficção se mesclariam, além de percebê-la num espectro literário maior em relação a Lima Barreto, e reduzido, em termos de contemporaneidade, em relação a Juliano Garcia Pessanha.

Palavras-chave: Marilene Felinto, repetição, presença, literatura e fracasso.

\begin{abstract}
This article uses Marilene Felinto's work to reflect upon an obsession of ideas in the literary field, drawing a parallel between her debut novel As mulheres de Tijucopapo (1984) and her most recent publication, the novel Obsceno abandono: amor e perda (2002). Having established the obsession with recurrences that problematize the presence of the narrators, starting with a failure of language, we believe that this parallel can elucidate the idea of writing as a kind of attempt - to write as a constant turn to the gesture of writing itself - which would inevitably call into question literature, its power and value, as well as the idealized idea of the work, especially, when the principle of unreason appears on our horizon. These questions are also surrounded by the analysis of the current suggestion that the author's biography and fiction would merge, in addition to situating her work on a literary spectrum that would include Lima Barreto, on the side of the canonical, and Julian Garcia Pessanha on the side of the contemporary.
\end{abstract}

Keywords: Marilene Felinto, repetition, presence, literature and failure.

\begin{abstract}
Resumen
Este artículo hace uso de la obra de Marilene Felinto para reflexionar sobre una obsesión de las ideas en el campo literario, trazando, por lo tanto, una línea entre su novela de estreno As mulheres de Tijucopapo (1982) y su última publicación hasta el momento, la novela Obsceno abandono: amor e perda (2002). Esclarecida la obsesión en reincidencias que problematizan la presencia de las narradoras, empezando por un estar en el fracaso del lenguaje, creemos que el rasgo pueda aclarar una idea de escritura aproximada de la tentativa; escribir como una vuelta constante al propio gesto de escribir, lo que inevitablemente pondría en cuestionamiento la literatura, su poder y valor, igualmente que la idea idealizada de obra, principalmente cuando el principio de desrazón surge en nuestro horizonte. Tales cuestiones se ven rodeadas todavía por el análisis de la corriente sugerencia de que, en la autora, narrativa de vida y de ficción se mezclarían, además de percibirla en un espectro literario mayor en relación a Lima Barreto y Juliano García Pessanha.
\end{abstract}

Palabras clave: Marilene Felinto, repetición, presencia, literatura y fracaso.

\footnotetext{
* Doutorando em Literatura Brasileira na Universidade de São Paulo (USP), São Paulo, SP, Brasil. (Dorcid.org/0000-0002-6150-9930. E-mail: thiagohfernandesp@usp.br.

${ }^{* *}$ Professor da Universidade Estadual do Piauí (UESPI), Teresina, PI, Brasil.
} 


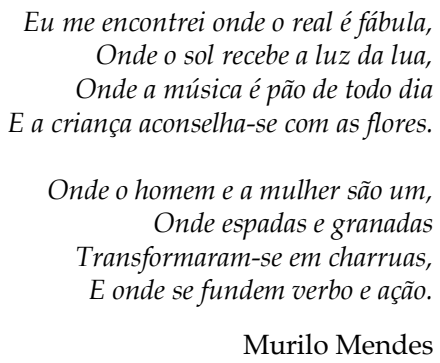

Aborda-se, comumente, a produção literária de um autor pelo conjunto, ou, ao menos, elegese um recorte que transcenda ao protagonismo de uma única obra. A tarefa não serve apenas ao trabalho de orientação histórica, mas, igualmente, de crítica, interessado que possa ser em dissonâncias; para frente ou para trás quando esteve a autoria melhor adequada ao projeto que, normalmente, a ela se impõe. Este olhar interessado pelo progresso, acostumado com a marcha sempre adiante, indispõe-se, não raro, com reminiscências outras, elementos que sugerem haver, a um só tempo, uma circularidade nesse mesmo trajeto, ou seja, reincidências, seja de estrutura, de apanhado temático, tipicidade de personagens, ou mesmo, apenas uma sensação de igualdade a que pouco se atenta a fim de caracterizá-la, mas que, de algum modo, assombra a leitura.

Este sentimento de repetição, se posto à prova no cruzamento entre textos, pode vir a revelar que a escrita literária se deixa tomar pela tarefa de "significar algumas coisas, embora às vezes das mais vagas e recônditas, como uma meditação sobre o ser e o nada" (Sant'Anna, 2003, p. 44), e de que tais "coisas" permanecem na malha do tempo, não se esgotam. Repetição que lança a obra, enquanto trama maior de textos, numa sala de espelhos, questionando mesmo o sentido de obra acabada, como no caso de Sérgio Sant'Anna, quando torna à superfície, pelas reincidências captadas em sua prosa, o trabalho mesmo da ficção. Projeto possível de se refletir sobre um work in progress na literatura. ${ }^{1}$

Não sendo propriamente a repetição um artifício manjado se a favor de uma velha estrutura de clímax, ou ainda, engano de uma linha irracional na esteira vanguardista, é nosso interesse pensar aquilo que volta entre textos feito uma condição obsessiva das ideias, na medida em que a escrita se concretizaria como uma prática perturbada pela fixidez de um algo que importuna, que perturba daí o sentido diabólico que cabe ao verbete obsessão nos dicionários. Aquilo que, aparentemente, pouco diz, agrega, mas que nos conduz - evocando um leitor empenhado - a outra obsessão, àquela de quando nos tornamos paranoicos pelo sentido através do detalhe, inclinados que somos a duvidar da gratuidade, acostumados que somos a certo princípio causal de verossimilhança.

Para evitarmos a generalização da abordagem buscamos uma aproximação com a literatura da autora pernambucana Marilene Felinto, riscando uma linha entre As mulheres de Tijucopapo (1982) sua estreia na literatura - e a novela Obsceno abandono: amor e perda (2002), até o momento, sua derradeira publicação. Com alguma liberdade, nosso interesse é primeiro validar um fator de ocupação da obra de Felinto, para, conseguinte, definir uma leitura nossa a esse traço obsessivo no que problematiza o fazer literário contemporâneo. Para isso, evocaremos o diálogo pontual com alguns autores, a exemplo de Blanchot (2011), na medida em que uma dualidade entre potência e fracasso se anuncia. Uma reflexão que caminhará a partir de reincidências indicativas de haver, em suas narradoras/personagens, um problema de presença, iniciado mesmo pela posição da autoria.

Principiando pelo óbvio, seria de se esperar que Obsceno abandono: amor e perda figurasse como produto da obsessão e, dada a similitude dos registros, confirmar As mulheres de Tijucopapo produto de autor já carimbado. Mas a opção que aqui se faz consiste em valorizar o campo de ideias obsessivas indiferentemente à sequência temporal das obras, o que já implica uma primeira correção: a repetição não seria propriamente uma volta entre obras, mas seria um entre determinante na escrita da autora. Logo, o voo pela matéria propriamente expressiva, literária, guarda o interesse final de pensarmos a escrita enquanto prática que se poderia dizer circunstanciada.

\footnotetext{
${ }^{1}$ A referência é direta ao work in progress utilizado no campo do espetáculo ou das artes visuais de modo geral como em Renato Cohen (1998), autor de Work in progress na cena contemporânea: criação, encenação e recepção.
} 
Um entre determinante que, contudo, não se transmute num caminho enviesado para alcançar o ponto no qual Felinto aparece deposta em sua literatura, numa sugestão automática de que ali residiria o exercício de uma ficção extremamente informada pelo biográfico. Sob a perspectiva de um conjugado de narrativas, poder-se-ia referir a uma Marilene-Rísia que "vive em guerra. Em pé de guerra [...] vivo em batalha, em bombardeio, em choque" (Felinto, 2004, p. 24). Uma grande malha discursiva de gênese comum, semântica severa, sem meio-termo, que seguiria ditando o tom, como em sua produção jornalística que nem sempre encontraria espaço adequado mediante desacordos ideológicos. Entretanto, a um ser da escrita possível de sublinhar não caberia um correspondente unicamente biográfico, pelo menos deseja-se que não o seja. Para tanto, há de se adentrar propriamente no campo de sua autoria.

Em As mulheres de Tijucopapo prenuncia-se: "Se eu pudesse dedicar essa história..." (Felinto, 2004, p. 17); a dedicatória que não acontece, restando simplesmente como uma nota introdutória, deixa a impressão de que somos pegos no meio do caminho de algo em processo; no agora do leitor onde já nada se dedica, já a impossibilidade que antecede o fluxo de uma narração muito particular pois não cessa de marcar diferença, ou seja, não se deixa presidir por uma postura indiferente. Ante o trabalho com a linguagem, uma primeira mostra de sua derrota. ${ }^{2}$ Talvez, não por acaso, o campo de ideias obsessivas referido trate, justamente, de presença, a dimensione sob a perspectiva da integridade corporal, vocal, mental e comunitária. Uma presença ameaçada, debatendo-se contra o estado de exílio que se deixa perceber, nas duas obras, pelos temas do afeto.

Ainda sob a perspectiva da não-dedicatória, se parece precipitado afirmar que depõe sobre o fracasso da linguagem e, neste caso, sugestão de sua impossibilidade ser um limite dado no indivíduo mesmo, cabe atentar que, igualmente, indica ausência de interlocutor. O destinatário inexistente não perdoa, assinala o primeiro estágio exilar ao nível da comunidade, em que o ambiente citadino revela um cosmopolitismo nada fraternal. A ausência de um alguém que do passado não se coloca no aqui agora do presente é, pois, o fado de mundo sem desabafo, sem conversa trivial, sem histórias de pé de porta, sem a graça pelo outro; um mundo recuado em verticalidade, de todo, sem ouvintes.

O retrato da cidade, a São Paulo em que se mora, é nada mais do que o concreto das imagens, uma questão de escala, seus prédios, rodovias, pessoas, luzes, uma particular constituição que não apenas se observa, se anota à distância, como um fotógrafo. Sua percepção, e a do elo conflituoso que ali se propaga, será sempre mais aguda quando impressa no desacerto do tempo individual, quando os edifícios "sequer me esmagam, passam sólidos, pesadamente desviando de mim, que não sou senão um cisco, um molambo que o vento atira para lá e para cá" (Felinto, 2002, p. 28). A constituição da cidade é um já que no outro é sentimento de atraso, tarde demais para vingar qualquer certeza, por isso mesmo é que a cidade grita em Rísia "passadista moralista", "salmo andante" (Felinto, 2004, p. 109), ela que se apegava ao Salmo 91 quando criança.

"Se eu pudesse dedicar essa história ...". Numa leitura retrospectiva, acompanhado o errar das narradoras, também uma universalidade conquistada pelo corpo que transgride à geografia de origem - como tão específico em Tijucopapo - pode ser sugerida. Transgredir, primeiramente, àquilo desprovido de um acerto no tempo, passar, então, a se deslocar por cenários que se sobrepõem em distinções e impossibilidades. Como que por contraste - explícito neste - já houvesse a ideia do corpo que a lugar nenhum pertence por repulsa mas, também, por direito adquirido de abdicar dos laços. O elo fraterno, pois, não é o único a se romper; sendo antes uma resposta à ruptura biológica, que se pode averiguar incisiva em nossa literatura, e de que a narradora de Obsceno abandono é mandatária, seu fracasso é duplo.

- Filhos! Você sabe muito bem que não quero filhos. Jamais vou ter um filho. Filhos fazem duas exigências básicas, a que sou incapaz de corresponder. Primeiro: amor. Filhos exigem amor. Segundo: dinheiro. Não tenho dinheiro, não tenho herança. [...] Além disso, esta infinita produção de gente no mundo, gente produzindo gente que

${ }^{3}$ A ideia de uma derrota da linguagem é usada em Juliano Garcia Pessanha, retomado à frente. 
produzirá gente, me provoca náuseas. Eu quase faço questão de ser um intervalo, uma pausa, um elo perdido dessa corrente infinita (Felinto, 2002, p. 72).

Afeto, corpo, pertencimento... certa concisão de vocábulos pelos quais flui este ponto primeiro na obra de Felinto, ponto que se antecipa na forma de um outro vocábulo, "mulheres". Aquelas de Tijucopapo, tal como se estampa na capa, inclusa a mãe de Rísia, seu local de nascimento; aquelas de Tejucopapo, no recôndito de Pernambuco e da história, "primeiro batalhão feminino armado" (Felinto, 2004, p. 183), paisagem de amazonas nos olhos de quem ali, naquele pedaço de terra ensolarada, acorda após longa jornada:

Umas dez. Eu pude vê-las pela janela montando o lombo de cavalos sem sela. Havia mulheres assim, então, a minha herança, mulheres que não fossem minha mãe. Eram umas mulheres de cabelos grossos como cordas arrastando pela crina do cavalo. Eram umas mulheres que eu vira nascer, só podia ser. Só podiam ser. Naquele meu livro, um livro de escola, um livro com uma figura vermelha a lápis de cera, era? Uma paisagem? Uma paisagem revolucionária de mulheres guerreiras. Eram mulheres que não eram minha mãe (Felinto, 2004, p. 180).

Mulheres autoras convidadas a constituir a coleção "Amores extremos" da editora Record, de que faz parte Obsceno abandono. Escrever orientadamente sobre o amor, seus extremos, e de maneira partilhada, sugere, tal qual em As mulheres de Tijucopapo, uma maleabilidade entre privado e público, particular e coletivo, nesse cruzamento de circunstâncias editorias e pulsões de ficção. Nessas mulheres narradoras há uma percepção muito aguda de uma memória corporal, de uma herança, que se percebe tanto imediata, quanto mais longínqua. Uma primeira dobra sobre a distinção de uma impessoalidade a que alcançaremos na medida em que tensionar o biográfico nos interessa.

A São Paulo dos homens-amores impossíveis, da aparência, da hostilidade, é capaz de acusar, nas mulheres de Marilene Felinto, total impossibilidade de reconciliação com a perda, a perda do amor prometido em Jonas e Charles, do convívio com o próximo, perda de si no todo. Habitar esse lugar irreconciliado, um lugar mediano, seria um modo possível de se acessar a memória, a herança citada, daí a sua impensada importância. Lugar mediano que se poderia materializar linguisticamente no "quase faço questão de ser um intervalo", pronunciado pela narradora de Obsceno abandono. Nem a total servilidade, quase escravidão, nem a ruptura desinteressada. De sofrer a perda a habitá-la, algo floresce como uma crença, necessário movimento de guerreio.

Frente a possibilidade de confluência dos rios, um só ego escritor e narrador, cabe arriscar que o gesto de escrita em Felinto, esta prática de que lança mão, seria também um gesto de irreconciliação, em um nível diferido, e não apenas uma contingência de suas narradoras. A declaração soa até mesmo óbvia se paralelizada à usual atenção que se concede ao ímpeto fervoroso apontado anteriormente, à raiva acumulada e declarada por autora e narradoras, já no seio da subtração, que faz da escrita uma representação do estar em guerra. O resíduo de experiência que permanece no fluxo da ficção, que a fomenta se se pode dizer, não encontraria representação possível, e com esta perda não se reconcilia, resvalando numa escrita eternamente fraturada.

A narrativa que representa a "fala" das personagens, se irreconciliada, já ascende caótica, porque se a crueldade do mundo é percebida como defasagem no sujeito, que seja então, através desta inadequação, que se olha para as histórias no mundo. É característico ainda a esta fala a dualidade, no sentido de que é grito, só que subalterno e silencioso pois segue esmagado pelo estado geral das coisas, aquilo que corre modorrento - "a palavra coisa é a própria indefinição de tudo" (Felinto, 2004, p. 115). É o inferno íntimo das mulheres de Felinto, inferno sabido daqueles que falam dentro, a voz vociferando dentro da cabeça: "minha atmosfera é a dos enterros, do silêncio dos velórios, cortados por soluços súbitos, por urros que eu não ouso dar e que morrem abafados dentro de mim" (Felinto, 2002, p. 27). Trata-se, pois, de uma duplicação maior, do sujeito, do tempo, como que sobrepondo dimensões.

Primordial a essa fala é cumprir um devir enunciativo. O registro, em meio a dita falta de interlocução, não emula nenhuma tentação terapêutica, não duplica a escrita - a nível das narradoras - no exercício do diário, das memórias, quando o elemento é elevado a instrumento de interpelação do meio. Cartas e outras tentativas de comunicação majoritariamente fracassam como a sequência de e-mails em Obsceno abandono que não encontram de jeito nenhum um nexo, 
sendo antes monólogos. Cabe menção, entretanto, à sintaxe que trabalha dobras como se houvesse nos arranjos da língua uma compensação, o virar de uma chave que não acontece.

Era Natal de 1964. Ismael seria o sexto filho de mamãe. Mamãe saíra para o centro de Recife com as lâmpadas queimadas de nossa árvore de natal. Nossa árvore de natal era o esforço de mamãe para nos dar um Natal. Já que papai tinha outras mulheres e não se interessava por nós. Papai tinha outras mulheres. Papai não se interessava por nós (Felinto, 2004, p. 27).

O relato da perda é, ao menos, o relato de que se sobrevive à perda de si mesmo, de alguma maneira escapar à morte, ter uma confirmação de existência pressuposta na virtualidade daquele que lê; constante na narrativa brasileira, de acordo com Regina Dalcastagnè (2012, p. 92), em que o leitor assumiria a posição de testemunha privilegiada. Mas, neste caso, só podemos ocupar este lugar privilegiado de interlocutor porque, justamente, se duplica o narrador cavando ele a sua virtualidade. Este lugar privilegiado de testemunha, quem sabe um ponto seguro à deriva da pessoa narrativa, nos possibilita o diagnóstico de um risco eminente, de que falhe esta "máquinaeu" (Felinto, 2002, p. 22) face um problema da língua - outra ponta do exílio - declarado e desdobrado obsessivamente. Na esfera do cotidiano, chama atenção os tropeços de seu uso.

Foram cinco anos de conflito e aflição: muitas vezes, como hoje, eu perdi a fala. Era tanta incompreensão que como se às vezes eu falasse outra língua, outro código, como se às vezes não me reconhecesse [...]. Conflito e aflição. Hoje mesmo, pela manhã, perdi a fala quando o porteiro interfonou. Às vezes estranho as palavras, como se estivesse louca. Conflito e aflição - palavras parecidas, em português, mas que não parecem português, do mesmo modo que as palavras "tenra" e "fuzil" soam como de uma língua estrangeira no silêncio das minhas cordas vocais (Felinto, 2002, p. 20).

A mudez é também acompanhada por momentos de gagueira, a preeminência desta causando a primeira, e, como relatado, datada desde a infância.

No dia da segunda esculhambação de mim mesma, o dia em que não matei Analice, amanheci gaga. E durante muito tempo em menina fui gaga e magra. A história de minha gagueira é longa e triste. É muito ruim ser pobre porque pode-se súbito ser um gago ou um magro. A história de minha magreza... eu era tão magra que me chamavam Rísia Popeye. Quando mamãe nos contou sobre papai e tia, eu fiquei gaga de novo. Agora eu já não gaguejo mais, agora eu emudeço de vez ou falo direto em língua estrangeira. Ou vou-me embora. Mas, não poder falar, ser gaga, é um verdadeiro corte, é o sinal mesmo da ruptura, é o espanto maior de todos. Ser gaga, então, me calava muito. Eu já fui uma verdadeira muda (Felinto, 2004, p. 57).

“Ah, se estivesse em mim não falar sobre nada. Eu queria poder me calar por dias e mais dias. Ah, se pelo menos eu pudesse falar em língua estrangeira" (Felinto, 2004, p. 49). Anotando a autora num espectro mais restrito, o estado exilar de que se fala - usual desencontro entre enunciação e ação - encontra num autor como Juliano Garcia Pessanha largo campo semântico. Muito do que escreveu, publicou, começando por Sabedoria do nunca (1999), reflete, em sua qualidade de escrita recuada, em modo de espera, a predominância de um fracasso da linguagem. Produziu, então, uma "ficção" - termo que se pode altamente problematizado no mesmo - que é sintoma de um mundo que não mais concebe a trama, a narrativa, as histórias por se contar. Escritos que guardam a ansiedade de quem espera, “agora, pela linguagem que já não venha derrotada" (Pessanha, 2015, p. 54).

Enquanto sujeito da exterioridade, nascido para fora do mundo, seu tempo é, por excelência, um tempo estirado que desconhece passado e futuro. Já em Sabedoria do nunca é notável a recorrência do termo "duração", algo que simbolizaria a essência mesma do sujeito em vias de se desfazer. Perder a duração, em Pessanha, resume-se assim: "Estou fora da trama do tempo e qualquer readmissão ficou interditada: minha eternidade é terrível e caíram as palavras" (Pessanha, 2015, p. 54). É de tal forma acuado que surge em sua trama da nãotrama, dispersa numa pluralidade de formas literárias, a sugestão de uma morte em vida, em 
que por mais que se beba do testemunho e de um self circunscrito como relato de caso clínico, improvável afirmar que se trate de relato bio-gráfico. ${ }^{3}$

Indagar pela duração, em meio a toda ordem de retirada, é similar a estar no encalço da presença, como se percebe nas referências colhidas em Felinto. Enfraquecida a vivência pela linguagem que a constitui, faz-se estratégia aderir ainda à língua corrupta, a um sentido de mentira, repetindo "todas as palavras mortas que já não dizem mais nada (mas as repetem sem parar, uma atrás da outra, na ânsia de não precisar dizer mais nada)" (Pessanha, 2015, p. 62). Neste sentido, assim como a perda, a raiva que impregna as narrativas de Felinto, projetada frequentemente em imagens catastróficas, de assassínio, seria, a princípio, um sinal da máquina-eu que toca o limite do insolúvel, não percebe caminho qualquer; prelúdio de uma fascinação por tudo o que a queda pode propiciar para que a um só tempo não se deixe corromper de todo, não perca de vez a duração.

Muito similar em ambos autores é a reiteração no seio de uma língua/linguagem, mecanismo básico, ou cacoete, que beira o estado delirante. No tocante ao fraca sso do sujeito, ele assim se percebe, em que a vigília do futuro ou a indagação do passado - este estar à espera da redenção - faz ordinário o presente, o gesto de reiterar parece tomar por objeto o próprio componente linguístico, ou seja, como se deixasse de ser motivado por ou contemplar a própria unidade da experiência. Escritas que armam armadilhas para si próprias, pois, se delirantes, apontam cada vez mais os seus contrários como mentira, como farsa, tentativa de teatro. Não havendo, por fim, transformação possível no horizonte, para onde retornar?

A consciência do trabalho está posta em Pessanha (2015, p. 54) ao afirmar que "a poesia se converte em religião para aquele que chegou ao limite do despossuimento da fala"; e assim o autor canta a sua tragicidade, a poesia é mais o seu transparecer do que o seu viver, o que bem se aclimata, deve-se salientar, na escrita que ora se instrumentaliza do filosófico, como apresentado pelo mesmo, para daí se desdobrar. Em alguma medida, a escrita relampejante de Pessanha é amostra de processo que garantiria uma extensão ao intelecto, posto que se afirma uma espécie de morte em vida; seria, então, um reverso da tendência de fazer viver o corpo, aparelhado tecnologicamente. Dever da poesia: "instaurar um novo mundo, pois o antigo já não tem mais sentido para nós" (Pessanha, 2015, p. 55).

Posto que limitada pelo fracasso, haveria total conexão entre essa expressão gaga e a forma (autor) que a anota? Gilles Deleuze se afeiçoou da possibilidade de distinguir níveis de gagueira na literatura. Podendo o autor fazer o personagem gaguejar, ou ainda, fazer variar o indicativo "falar", quando sobre a vocalização da personagem, restaria ainda uma opção, "quando dizer é fazer... é o que acontece quando a gagueira já não incide sobre palavras preexistentes" (Deleuze, 2011, p. 138), ou seja, quando o autor se torna gago da língua. Deixando-o em aberto, o processo seria da ordem de uma desestabilização linguística. Enquanto morto em vida, o eu de Pessanha que se apresenta é aquele no instante da escrita, um eu que idealizadamente escrevesse à mão, sua obsessão (gaguejo) seria o acaso da não narrativa. Ao mesmo tempo, um eu que nos desmente, parece afeiçoado da edição digital, uma escrita que se acalma, matéria do que se faz com certa propriedade.

Agravando-se as diferenças, a matéria de que se constitui os escritos de Felinto não é tão radical em extemporaneidade; permite-se olhar para o corpo que a guarda, não descende de uma realidade asséptica, mas é feita de barro e lama. A língua/linguagem que a constitui, a fala das narradoras, mesmo sob o risco de dobrar-se sobre si mesma (opaca), faz-se perceber como resíduo mesmo da condição trágica, mantendo-se o agrave entre forma e expressão. Se o vislumbre de Deleuze através do gaguejo é, uma vez mais, o delírio da língua pela literatura, o como tornar palpável um fora da linguagem, encontrar na língua - tida como oficial - o estrangeiro da língua, qualquer indicação de transformação possível surgirá aos desdobres dessa gagueira, do improvável. A poesia capaz de inaugurar o novo, quererá indicar, no limite, os gestos em si, mais ou menos arbitrários, prenunciados no gaguejo de uma escrita, sendo esta a radicalidade de Felinto.

Consideremos, pois, a indicação, pelas obras, de uma "língua estrangeira". Entre a sua recusa, o seu desejo, e o risco de se bastar no uso do inglês, pincelado nas duas obras, a expressão dificulta

\footnotetext{
${ }^{3} \mathrm{O}$ que justifica no autor o uso do termo heterotanatografia.
} 
um cerco interpretativo. Trilhando pelas evidências tratadas, é provável que essa outra língua, assim como os desejos virulentos do ódio, não representaria apenas parada do processo. Seriam pontos de alcance - respostas - a partir da pergunta inexistente de como superar a inoperância, o cansaço da língua - pois é cansada a língua de saber de sua impotência -; cansaço da ida que data de tempos idos, no remoto de outros corpos a se perder de vista, da mãe, da avó... Respostas advindas de um estado de trabalho contínuo, trajeto caótico, reiterativo, mapa de substantivos e sujeitos como que reproduzidos em decalque - pai, mãe, mamãe, São Paulo, Recife, Luciana, Nema, Valmir, casa, égua, sexo, ódio, inferno... - que são a gagueira da língua.

Que sejam um "fim de linha", aspecto desesperado face uma destinação de Sísifo, o praguejo e o estrangeirismo visionado fazem ainda com que resplandeça a língua como instrumento de validação do desejo. Trabalho íntimo, portanto, de refazer a fala até restituir ao sujeito o poder de evocação, sonho da língua que move o redor, confirma de direito criar e destruir; por seu mistério, por sua intangibilidade, é trabalho que mantém um feitio desprogramado, que desconhece rota. Movimento arriscado, pois sugere uma volta sobre os fatos, e não apenas uma dobra opaca da língua, e assim os desloca, tal como os sentimentos, os objetos, os dias de um antes e depois, ${ }^{4}$ questiona essa disposição evolutiva arriscando-se a pousar no inóspito, na pura guerra, no encantatório da língua - maldita - no arcaísmo do corpo.

Criar e destruir, palavras flerte com a busca aparente por um estar ulterior à perda, à desilusão, à desgraça, a tudo que interferiria na "inauguração pessoal" (Felinto, 2002, p. 52) e que corrói as páginas da autora. Como que estando no encalço do que passou ainda no porvir, as narradoras se mantém em trabalho, chegam à linha limite do desejo estrangeiro e do praguejo maldito, linha em que para além de seu traçado cairia a presença, sempre sob ameaça, em pleno abandono. Provável que a loucura seja este outro lado, um estado catatônico ou, para não se apegar à patologia das palavras, um "território" qualquer de difícil comensuração, "territórios" selvagens fixados pelas narradoras em formas de retratos da infância.

Na memória de Rísia permanece a figura de Severino, apelidado por todos de Severina Podre, menino desumanizado que não mais se reconhecesse como gente, amarrado para que permanecesse sob o controle da mãe. Diziam que Severina Podre já havia esfaqueado um homem. Rísia teme, mas, ao mesmo tempo, admira a solidão, o desapego absoluto daquele. Também em Obsceno abandono conclama-se os loucos da infância, Macsuel e Maria Doidinha. Alcoólatra e obscena esta, errante e delirante aquele, o primeiro pronunciava "Eu estou aqui mesmo! Não tenho vergonha de negar que estou aqui mesmo!" (Felinto, 2002, p. 18). Mas o fascínio tão logo se desfaz, medo de uma condição tão absoluta, "a margem que não suporto. A margem não. Eu prefiro o meio da multidão, a massa, os elos da corrente que nos conduz ao nada mas que nos conduz juntos. [...] Não a solidão dum louco" (Felinto, 2004, p. 126).

$\mathrm{O}$ temor em adentar em tais estados limiares parece justificado em ambas narradoras por uma predisposição pela perda da estabilidade emocional, mas, igualmente, pela perseverança da negatividade. A raiva deve ser domesticada pois equivale a uma série outra de estados igualados entre si pela marginalidade, tornar-se "uma prostituta, uma homossexual, uma louca, uma bêbada, uma bandida, uma marginal. E, não, eu não sou de aguentar a margem da vida. Na margem sou fio que se quebra" (Felinto, 2004, p. 24). Pois, como medida de segurança, almeja-se a cotidianidade das coisas, a ordem romântica dos fatores que acaba, entretanto, por permanecer como um guia subjetivo e idealizado. Ao desejar a correção do privilégio daqueles que não distorcem certos preceitos sociais, dos que adequadamente se adequam, recusa-se a derrota da predisposição.

A loucura, pois, seria uma derrota, ainda que se assuma a simpatia por aqueles indivíduos em seu mistério particular; enigma, ruptura intransigente com o resto do mundo. "Eu estou aqui mesmo!", simbolicamente único repertório possível para toda e qualquer situação, uma sentença no lugar de um nome, de uma história. Um estar absoluto que não condiz com a presença garantida pela conquista da palavra. Os loucos da infância são acima de tudo solitários, presos ao tempo de um dia,

\footnotetext{
4 “[...] o desfile que poderia muito bem ter sido naquela manhã em que eu estivera corrupiando feito uma marmota sem nada com que brincar; mas o desfile que só poderia ser de tarde, porque o céu nunca foi perto, e porque os acontecimentos só podem vir uns depois dos outros. Uma injustiça” (Felinto, 2004, p. 175). Superação do ressentimento da menina Rísia.
} 
tal qual a eternidade que se pode colher no testemunho de Maura Lopes Cançado (2015, p. 25), "a marca da eternidade que ostenta a loucura" e que assombrava a autora; ao passo que as personagens de Marilene Felinto são pegas no encalço da trajetória, da reverberação incessante.

O fascínio pelo estado limiar existe, como visto, persiste em meio à ameaça do desaparecimento, mas ele não representa, ou não se confunde, com o real fascínio pela transgressão que guarda a plenitude do instante que cessa de perguntar, matéria de fetiche, acertada sedução pelos bichos. No estudo vocabular feito por Grigoleto e Camargo (2011) em As mulheres de Tijucopapo, "égua" aparece como um dos cinco termos mais recorrentes.

Se eu pudesse somente grunhir... Oh, se eu pudesse ser um bicho eu seria uma égua, uma égua que saísse em disparada arrancando patacas de lama da campina encharcada ou fazendo poeira do barro seco das serras. E assim eu esqueceria, meu Deus, que perdi o amor de um homem. [...] E eu andei quinhentas mil milhas tentando ser a égua que até hoje tento e não consigo ser (Felinto, 2004, p. 135).

Se não égua, cavalo, que em Obsceno abandono aparece como índice de identificação. Se a mulher sem nome que nos fala na novela se diz às voltas do arrependimento é porque muito insistiu em tornar o outro uma realidade, insistiu no vínculo contrariando a maldição da solidão. Se o gesto aporta na falência, num quase não saber mais de si, guarda ainda, apesar de tudo, o seu entendimento na figura de um cavalo desacreditado que vem correndo por fora, o animal puro músculo, que corre. A reverência à animalidade se justifica por aquilo que podem os animais, sinônimos de força bruta, portadores de um estar impassível de bicho.

O fetiche da transgressão, frequentemente acessado pelas narradoras de Felinto, se encontra na infância, sendo assim, original. Fetiche aproximado do sacrifício - matar a língua, matar o outro, matar a si - como se Rísia e a mulher sem nome finalmente pudessem esclarecer a sua crença: o depois, que não é temporal, mas o logo que se segue ao desfazer da forma, face oculta impensada. Desfeito está, feito está. Portal para a inauguração pessoal. Esta seria, pois, a poética responsável por um mundo novo por vir, a solução estética que se dá para a vida (Felinto, 2002, p. 72), restando da palavra um sentido expandido de criação.

A passagem ao desejo - erótico - seria a base fundamental dos romances como fórmula para se tocar na continuidade, algo similar ao que se refere Bataille (2014). Desejar o corpo quando da necessidade de desnudar o outro, e de se fixar, muitas vezes, na potência da fisicalidade oposta - incluso os animais -, desejar aquilo que se adora em sua existência hipotética. O gesto de violar é primordial nessa passagem, pois Bataille (2014, p. 42) trata de uma dissolução das formas constituídas, "dessas formas de vida social, regular que fundam a ordem descontínua das individualidades definidas que somos". Contudo, "há busca da continuidade, mas, em princípio, somente se a continuidade, que só a morte dos seres descontínuos estabeleceria definitivamente, não prevalecer" (Bataille, 2014, p. 42).

Se temida é a loucura, duvidada em sua transgressão, a outra possibilidade apontada se poderia nomeada como desrazão, esta a matéria de fetiche. Por desrazão, sob a guia de Peter Pal Pelbart, entende-se o pensamento do fora, aquilo que é exterior ao homem. O autor adverte: "na loucura, o sujeito ficaria exposto sem proteção alguma à violência des se Fora, e sem condições de estabelecer com ele um vaivém ou uma relação" (1993, p. 97). ${ }^{5}$ O que está em jogo, portanto, na crença basilar das narradoras é, pois, esse vaivém, cabendo a Bataille (2014, p. 42) o arremate de que a vida descontínua não é propriamente condenada, mas "colocada em questão. Ela deve ser perturbada, desordenada ao máximo".

Os termos de uma obsessão em Marilene Felinto, a partir de duas produções distanciadas em sua literatura, parecem mesmo superar esta relação imediata entre dois objetos quando, retomando

${ }^{5} \mathrm{O}$ autor discorre sobre desrazão passeando por Foucault, Blanchot e Deleuze, mais propriamente por sua relação dialógica. 
aqui a ideia inicial, a obsessão das ideias não estaria entre as obras, mas seria um entre na literatura da autora. Assim sendo, podemos dizê-lo o meio-termo - improvável num primeiro contato - que problematiza a ideia de literatura face aos seus contrários: a literatura face ao seu estar no tempo e ao seu não estar, face ao valor e ao seu poder de interferência e sua impotência flagrante.

É necessário então estar atento ao gesto de escrever como tentativa. A cada nova incursão uma nova tentativa, voltar ao princípio das coisas, como se por elas não se houvesse passado. A obsessão das ideias representaria, pois, o próprio colocar-se em produção, na medida em que o primeiro aporte deste retorno, a volta inaugural, é sobre o escrever que se confessa um gesto no porvir, pouco seguro de acordo com os critérios que lhe legitimam o valor de saída, afinal se está produzindo literatura. Digamos que as narradoras de Marilene Felinto e suas reincidentes desilusões, sua fala siamesa, não configuram bem uma repetição, mas são antes indícios de que o que se repete, em verdade, é o ato de voltar à escrita por parte da autora, mais uma vez e tentar. "Preservar no recomeço do que para ele (o autor) jamais começa", sugere Blanchot (2011, p. 15) frente aos autores que permanecem obcecados em retomar o já dito. A literatura pode pouco. Sugestão nossa para uma nova nota introdutória face a não-dedicatória de Felinto.

Essa problematização da literatura em seu pouco poder é, como se percebe, da ordem da permanência, ou da duração ou da presença, termos que se avizinham e extrapolam os limites da ficção. A literatura, pois, pega num golpe em que passasse a ser produto daquilo que inocentemente poderia dizer apenas tematizar - face sua porosidade ao comum social - estaria ferida em sua presença, o que vale a estar ferida em integridade. Estar exposta na ilusão de se salvaguardar pela biblioteca, ilusão de depor sobre a grandiosidade de uma tarefa distinta da vida ordinária, quando escrever se aparenta de um enredo fadadamente egoico; tomadas que lhe confirmariam o valor pela duração no tempo, tarefa cada vez mais ingrata na dispersão contemporânea.

Afirmar, pois, o pouco poder é fazer pensar por contaminação, é questionar a integridade, ainda que indiretamente, da literatura canônica em suas linhas estagnadas de acesso e seu valor agregado de produto cultural, a literatura que é empenhada e fala por; no outro extremo, é questionar a desenvoltura da literatura contemporânea, a sua competência, algo que pode ser ilustrado numa parcela da crítica que muito se queixa, como Alcir Pécora, de que aos "autores sérios" já caberia a possível destinação de não mais escrever frente a consciência de tornar-se "apenas um cotejador e copiador de uma montanha de outros escritos, já produzidos, sem senso nem motivo, a não ser o de girar a própria engrenagem burocrática de escrever" (Pécora, 2010). ${ }^{6}$ Injustificável, portanto, para o crítico, é a conversão da escrita em tarefa ordinária, maquinal como qualquer outra, uma tarefa fora de crise.

A diferença que podemos suscitar em Marilene Felinto, e tomá-la como uma outra face a ser considerada no campo da literatura para além desse pequeno recorte, é um entendimento diferido do fazer literário que parece expor suas limitações e, de tal forma, ao se deparar com o silêncio, barreira inicial, estar em estudo de si; e este seria o ponto que mais parece implicar a autora em sua obra, algo que nos mantém ainda atentos ao legado da gagueira, evitando assim estar à procura de um mapa originário biográfico. “Todo problema de origem é sempre insolúvel", fiquemos, pois, com a frase de Lima Barreto em seu Diário do Hospício (2017, p. 55) como advertência ao engodo de certas aproximações explicativas.

Felinto, assim como o citado Lima Barreto, são autores para quem o silêncio representou, antes de tudo, um risco iminente, senão uma condição primeira reatualizada ao longo do tempo. Silêncio contornado em ambos pela busca da instrução, pelo rompimento da lógica local em sua face mais arbitrária. Primeiro grande deslocamento espelhado entre a geografia e o extrato social ao modo das cidades é passar à condição de passageiro, contundentemente expressa pelo assento de Rísia/Marilene nos aviões da extinta Varig onde antes trabalhara sua tia: "Pois uma vez, eu jantava no avião indo em viagem para Recife e me lembrei assim de tia e de eu menina e as lágrimas caíram em bagas e ensoparam os pãezinhos do meu jantar e eu solucei tanto que quase vomitei" (Felinto, 2004, p. 47).

\footnotetext{
${ }^{6} \mathrm{O}$ autor traça um paralelo com a leitura de Bartleby por Giorgio Agamben.
} 
Curiosa constatação de Barreto (2017, p. 58), enquanto observador privilegiado dentro do hospício: aqueles de caráter doutoral em vias da loucura eram vitimados pelo mutismo, como se numa jogada do acaso, este viesse através do empenho, ceifando-o de vez. Não que se tome como verdade, mas não deixa de ser significativo o movimento de retorno operado por Rísia em As mulheres de Tijucopapo, um movimento no já, partir e tão logo voltar à lonjura, à miséria, o que o faz ter um caráter vital, longe de ser ilustrativo. De ganho improvável, a volta garantiria, ao menos, vislumbrar novamente o brilho da língua, não mais opaca, o brilho dos "nomes bonitos" (Felinto, 2004, p. 115) que conformam Tijucopapo.

Afirmamos, com efeito, que a enunciação das narradoras-personagens explicita uma contrariedade, é pungente ao mesmo tempo em que exibe sua fragilidade, que apesar de tanto e tudo, ainda assim, pode-se pouco. Inadequado seria unificar o discurso da autoria de modo indiferente, irrestrita comutação, nos termos de Dante Moreira Leite, entre sonho e vigília, ou seja, não como complementariedade, mas identificação, "quando a vigília e o sonho tendem a confundir-se -, desaparece a tensão básica, fundamental para a ficção, em qualquer de seus níveis" (Leite, 2007, p. 45). Se isto fosse sobre mim, eu, eu não teria nada a dizer - nova sugestão nossa enquanto não-dedicatória. Pois eu sou aquele constante no fracasso que sempre esteve, o fracasso do silêncio posto aos olhos no retorno simbólico à terra seca das origens, seca da cheia das palavras. Logo de partida, portanto, a exigência do imaginário, único modo de entrever, não obstante, um discurso que supere o silêncio sem nunca o esquecer, irreconciliado, pois não pretende suprir a dívida de se escrever no influxo de uma miséria já impessoal.

Este problema do empenho da fala será tão mais sinuoso quanto mais se aperceba o quanto a literatura aproxima iniciativa e derrota, quanto mais exibe o fracasso que pouco se explica pela imperfeição estética. Quando Lima Barreto $(2017$, p. 36) afirma que a literatura ou mata ou dá o que a ela se pede, ali se confessa triste e inteiramente deposto em seu escrito, como afirmar que sim, trata-se de mim, devo eu ter o que dizer. Mas o silêncio para o qual retorna como condição prevalente, como distingui-lo de outros retornos ao silêncio, como o da própria Marilene Felinto, dezoito anos separando seu Obsceno abandono deste ano de 2018?

Dizemos que Felinto expõe sua limitação e não pretende superá-la, a limitação de sua literatura, não recorrendo ao escopo das grandes ideias, como sugerira Pessanha, acuada, a literatura, a reagir frente a um mundo varrido de mistérios; e em meio a adversidade arriscar uma relação com o fora, este que conforma propriamente o teor de sua ficção, um fora "de onde não estivesse excluído aquilo que precisamente sempre fizemos questão de excluir, por medo e insegurança - a saber, a permeabilidade ao Acaso, à Ruína, à Força e ao Desconhecido" (Pelbart, 1993, p. 99). Talvez resida aí a crença no logo após que não é temporal; talvez aí seja possível encontrar algum traço de vitalidade, para além do pouco poder da literatura e do sujeito em eterna fratura, de tal forma a comungar a obra do desejo de inauguração pessoal que intentam as mulheres de Marilene Felinto.

A aventura descrita acarreta, contudo, uma condição, a de que "o Pensamento do Fora arriscase num jogo com a Desrazão do qual ele nunca sai ileso, na medida em que não saem ilesos o Ser, a Identidade, o Sujeito, a Memória, a História e nem mesmo a Obra" (Pelbart, 1993, p. 96). A obra de Marilene Felinto - limitada aos dois romances aqui abordados - não sairia ilesa justamente em relação à sua continuidade, como se dissesse que deverá ser encontrada fora do curso comum da literatura, fora dos critérios habilitados de orientação a que comumente se aplica ao objeto literário e, neste sentido, correr mesmo o risco de nunca ser encontrada. Se há um leitor projetado em seu horizonte ele é disforme, imprevisto, improvável, porém ele é também um ato de fé, revelado nele a inauguração pessoal que rebateria o silêncio; não um silêncio no qual se afunda, afirmando ter sido em vão todos os esforços, mas aquele que termina por se apequenar na perspectiva editoral.

\section{Referências}

BARRETO, Lima (2017). Diário do hospício \& O cemitério dos vivos. São Paulo: Cia das Letras. 
BATAILLE, Georges (2014). O erotismo. Tradução de Fernando Scheibe. Belo Horizonte: Autêntica.

BLANCHOT, Maurice (2011). O espaço literário. Rio de Janeiro: Rocco.

CANÇADO, Maura Lopes (2015). Hospício é deus: diário I. 5. ed. Belo Horizonte: Autêntica.

COHEN, Renato (1998). Work in progress na cena contemporânea: criação, encenação e recepção. São Paulo: Perspectiva.

DALCASTAGNÈ, Regina (2012) Literatura brasileira contemporânea: um território contestado. Vinhedo: Horizonte.

DELEUZE, Gilles (2011). Crítica e clínica. 2. ed. São Paulo: Editora 34.

FELINTO, Marilene (2002). Obsceno abandono. Rio de Janeiro: Record.

FELINTO, Marilene (2004). As mulheres de Tijucopapo. 3. ed. Rio de Janeiro: Record.

GRIGOLETO, Grace Gonçalves; CAMARGO, Diva Cardoso de (2011). Análise de cinco vocábulos recorrentes e preferenciais na obra As mulheres de Tijucopapo, de Marilene Felinto. Rev. Est. Ling., Belo Horizonte, v. 19, n. 2, p. 141-165, jul./dez.

LEITE, Dante Moreira (2007). Ficção, biografia e autobiografia. In: LEITE, Rui Moreira (Org.). O amor romântico e outros temas. São Paulo: Editora da UNESP, p. 43-52.

PÉCORA, Alcir (2010). O inconfessável: escrever não é preciso. Sibila. Disponível em: https:/ / bit.ly/2uR3DhL

PELBART, Peter Pál (1993). Da loucura à desrazão. In: PELBART, Peter Pál. A náu do tempo-rei: sete ensaios sobre o tempo da loucura. Rio de janeiro: Imago.

PESSANHA, Juliano Garcia (2015). Sabedoria do nunca. In: PESSANHA, Juliano Garcia. Testemunho transiente. São Paulo: Cosac Naify.

SANT'ANNA, Sérgio (2003). O voo da madrugada. São Paulo: Companhia das Letras. 